\section{Yang Zhijiu \\ MARKO POLO RZECZYWIŚCIE BYŁ W CHINACH - POLEMIKA Z FRANCES WOOD ${ }^{1}$}

Opublikowana w 1995 r. książka Czy Marko Polo przybyt do Chin dr Frances Wood z British Library zwróciło uwagę zarówno badaczy chińskich jak i zagranicznych. Już przed jej publikacją niektórzy uczeni wypowiadali wątpliwości, czy Marko Polo był kiedykolwiek w Chinach. Kwestie te jednak były dyskutowane jedynie w krótkich artykułach lub zaznaczane w przypisach. Dr Wood podjęa ten problem w osobnej monografii, w której cytuje 97 prac, włącznie z Make Boluo jieshao yu yanj (Wprowadzenie do studiów nad Marko Polo) wydanej przez chińskiego uczonego Yu Shixiong. Poza wstępem i konkluzją, piętnaście rozdziałów poświęconych jest przedstawianiu jej punktu widzenia, referuje ona także wszystkie poprzednio formułowane wątpliwości i zastrzeżenia. $\mathrm{Z}$ tego powodu książka warta jest wnikliwego przeanalizowania. Ze względu na szczupłość miejsca omówię tutaj tylko najważniejsze argumenty dr Wood.

\section{Przegląd wcześniejszych dyskusji}

We wstępie dr Wood stwierdza, że to od Craiga Clunasa, ucznia słynnego niemieckiego badacza Mongolii, Herberta Franke, dowiedziała się o wątpliwościach związanych z podróżami Marko Polo. Jednakże w opinii Franke problem, czy Marko Polo i jego wujowie kiedykolwiek dotarli do

${ }^{1}$ Frances Wood, Did Marco Polo Go to China? London, 1995. Studium to zostało opublikowane $w$ Social Sciences in China, 1998, nr 3, W tekście zostały dokonane niewielkie skróty. W nawiasach kwadratowych zostały dodane objaśnienia tłumacza i Redakcji.
Chin, pozostaje nierozstrzygnięty ${ }^{2}$. Odnotowuje on kilka punktów budzących - jego zdaniem - wątpliwości w książce Marko Polo, na przykład, zajmowanie przez niego urzęu gubernatora w Yangzhou, oraz wzieccie udziału w oblężeniu Xiangyangu jako inżyniera artylerii. Polo nigdy też nie wspomina o herbacie, ani o piśmie chińskim. Jak pisze Franke „Wszystko to wzbudza wątpliwości w kontrowersyjnej kwestii, czy rodzina Polo spędziła długi czas w Chinach" (...)

Wydaje sie jednak, że dr Wood nie zwróciła dostatecznej uwagi na kolejne stwierdzenia w pracy Franke. Po odnotowaniu watpliwości, wymienionych powyżej, stwierdza on: ,jakkolwiek by było, przed uzyskaniem definitywnego dowodu potwierdzajacego, że książka Opisanie Swiata Marko Polo $w$ rozdziałach poświęcone Chinom jedynie przedstawia informacje zapożyczone z innych źródeł, prawdopodobnie perskich (niektóre zwroty, których używa, sa bowiem perskie), musimy zastosować wobec relacji tego podróżnika zasadę rozstrzygania wątpliwości na jego korzyść i stwierdzić, że mimo wszystkich wątpliwości był on w Chinach". Innymi słowy, wprawdzie zasadne jest stawianie pytania, czy Marko Polo kiedykolwiek był w Chinach, ale nie możemy odrzucać $\mathrm{z}$ góry przypuszczenia, że był on tam, zanim nie uzyskamy przekonywujących dowodów. Profesor Franke jest rozważnym i rzetelnym naukowcem, ma poczucie odpowiedzialności w formułowaniu' konkluzji i zawsze pozostawia miejsce na wątpliwości. Jednakże Craig Clunas i dr Wood poszli krok dalej zdecydowanie negując możliwość pobytu w Chinach Marko Polo. Czy podają oni na to niepodważalne dowody?

Warto nadmienić, ze zastrzeżenia wymienione przez profesora Franke były podnoszone już wcześniej. Już w latach dziewięćdziesiątych XIX wieku, Henry Yule, brytyjski znawca Marko Polo, stwierdził we wstępie do pierwszego tomu swojej pracy The Book of Marco Polo, że podróżnik ten opisujac Chiny pominął w swojej książce wiele spraw. I tak nie informuje on, na przykład, o: 1) Wielkim Murze; 2) piciu herbaty; 3) krępowaniu stóp kobiet; 4) wykorzystywanie kormoranów do połowów ryb; 5) sztucz-

${ }^{2}$ Herbert Franke, ,Sino- Western Contacts under the Mongoł Empire", Journal of the Royal Asiatic Society, Hong Kong Branch, June 1966, s. 49-72. W tym artykule autor poświęca tylko Asiatic Society, Hong Kong Branch, June 1966, s. 49-72. W tym artykule autor poświęca tylko jedna stronę krytyce Marko Polo. Craig Clunas w artykule "The Explorer's Tracks", opublikowanym w chinskim suplemencie do The Times, datowanym na 14 kwietnia 1982 , przytacza studium profesora Franke, i sugeruje, że Marco Polo mógł czytać jakieś rodzaje przewodników w języku perskim. Autor tej polemiki kwestionuje słusznosć stwierdzenia Clunas w swoim artykule opublikowanym w 10 numerze Globe z 1982 (został on również włączony do jego książki Yuanshi sanlun [Trzy studia U historii dynastii Yuan], Beijing 1985, s. 127-132, jak też do Make Boluo jieshao yи уапjiu [Wprowadzenie do badań nad Marko Polo], pod redakcja Yu Shixionga, Beijing 1983, s. 52-58). 
nej inkubacji jaj; 6) druku książek; 7) piśmie chińskim; 8) innych intrygujących technikach i zwyczajach.

Występuje w niej również wiele nieścisłości, na przykład:

a) używa on tatarskich, bądź perskich nazw miejscowości;

b) często niezbyt jest dokładny w swoich wyliczeniach daty śmierci Czyn-gis Chana, podawaniu listy jego sukcesorów, jak też w opisie stosunków między najważniejszymi członkami domu panującego;

c) najbardziej zagadkową dla Yule sprawą jest oblężenie Sayanfu czyli Xianyangu. Wady książki Marko Polo, jak to jest zaznaczone przez Yule, sa zatem daleko bardziej złożone, mimo tego nie podejrzewa on wszakże, iż jest ona tylko kompilacją ze źródeł perskich.

Yule przedstawia również niektóre wyjaśnienia możliwych przyczyn tych pominięć. Odnośnie braku wzmianki o Wielkim Murze stwierdza on, że: „Wielki Mur nie jest nigdy wymieniony, chociaż mamy podstawy przypuszczać że autor miał go na myśli $\mathrm{w}$ jednym $\mathrm{z}$ fragmentów swojej książki [tom I rozdział 591 podczas jej dyktowania". Pisze on również w przypisie, „Humboldt potwierdził opinię, którą niejednokrotnie wyrażałem, że nie można wyciągać z przemilczeń autora zbyt daleko idacych wniosków. Powołuje się on na bardzo znaczacy i zaskakujacy przykład: $w$ archiwach Barcelony nie ma nawe wzmianki o triumfalnym wjeździe Kolumba do miasta (...). Podobnie w archiwach portugalskich nie ma śladów podróży Amerigo Vespucci odbytych w służbie jej korony ${ }^{3}$. Jeśli by przyjać kryterium wspominania w książkach podróżniczych poszczególnych faktów za miarę, czy dany opis podróży zawiera materiały pochodzące $z$ pierwszej ręki, to można by wyciągnąc wniosek, że żaden opis nie wyszedł spod pióra naocznego świadka (...) Dlatego nie powinniśmy być nadmiernie krytyczni w odniesieniu do Marko Polo. Jes zaskakujące, że dr Wood przykłada tak wielką uwagę do krótkiego stwierdzenia profesora Franke, a nie zwraca uwagi na wypowiedź słynnego orientalisty Paula Pelliota, który obszernie komentuje książkę Marko Polo, jak też do jego wyjaśnień pomyłek i pominięć autora.

Henry Yule, The Book of Sir Marco Polo or Travels of Marco Polo. Pierwsze wydanie tej książki ukazało się w 1870, drugie w 1874, a trzecie wydanie, poprawione przez francuskiego uczonego Henry Cordier, w 1902 ze wstępem Cordiera wskazującym jego poprawki. Cytaty w tym artykule pochodzą ze „Wstępu do trzeciego wydania", s. 110-112

\section{Zastrzeżenia do udokumentowanych dowodów}

Dr Wood, wielce ceniąc sobie opinie profesora Franke, zbyt małą wage przykłada do jego napomnień dotyczących „niepodważalnych dowodów". Co gorsza zaś, traktuje ewidentne dowody jako „opowieści zasłyszane". Świadczą o tym dwa przykłady:

Zgodnie z Opisaniem Świata, Polowie otrzymali zgodę na opuszczenie Chin w celu eskortowania mongolskiej damy imieniem Cocachin do Persji drogą morską razem z perskim posłańcami: Oulatay, Apusca i Coja. Ich nazwiska zachowały się w chińskiej transkrypcji w cytacie z Zhanchi, w rozdziale Jingshi dadian (Wielki Kanon Dla Rzadzenia Światem) w rozdziale (juan) 19418 dzieła Yongle dadian (Wielki Kanon Panowania Yongle, znanym też jako Wielka encyklopedia Yongle). Zostali oni wysłani na mocy dekretu cesarskiego „do króla Aluhun [u Marko Polo „Argon"] szlakiem Maba'er [„Mabar" u Marko Polor. Jak widać dokładnie pokrywa się to ze sprawozdaniem Marko Polo. W oparciu o te odkrycia, autor opublikował artykuł „Chińskie zapiski odnoszące się do wyjazdu Marko Polo z Chin", zaaprobowany przez Francisa Woodmana Cleavesa, profesora z Uniwersytetu Harwarda, który przedstawił szczegółowo to stanowisko w arłykule w Harvard Journal of Asiatie Studies ${ }^{4}$. Dr Wood czytała wprawdzie oba artykuły, ale nie zgadza się z ich konkluzją. „Jedyny problem z tym fascynującym odkryciem — jak pisze — polega na tym, że w żadnym ze źródeł, zarówno chińskim, jak też u Rashida, nie ma najmniejszej wzmianki o tym, by księżniczce towarzyszył jakiś Europejczyk czy Włoch (...) Można również zakładać, że historia ta została zapożyczona z innego źródła" (s. 32).

Profesor Cleaves wykazuje, że ani Polowie, ani sama księżniczka nie sa wymieniani w tych chinskich fragmentach. Dr Wood podważa ten dowód pośredni, pisząc, że nawet jeśli podróż „księżniczki" miała miejsce, to jest to kolejny przykład powtarzania przez Marko Polo dobrze znanych historii (takich, jak na przykład, inwazja na Japonię czy powstanie Wang Zhu)" (s. 137). Czy wydanie za granicę za mąż mongolskiej dziewczyny było jednak ,powszechnie znanym wydarzeniem"? żadnej wzmianki na ten temat nie ma w Yuanshi (Historii dynastii Yuan), zebranych pism uczonych $\mathrm{z}$ okresu Yuan, ani w innych dziełach z tego okresu. Musimy pamiętać, że dziewczyna ta nie pochodziła z cesarskiego domu, a była je-

Francis Woodman Cleaves, „A Chinese Source Bearing on Marco Polo's Departure from China and a Persian Source on his Arrival in Persja", Harvard Journal of Asiatie Studies , Vol. 36 (1976), s. 181-203. 
dynie córką zwykłego wielmoży z mongolskiego plemienia Bayaut, dlatego też nie była warta szczegółowej wzmianki. Co ważniejsze, ten fragment $z$ Jingshi dadian odnosi się do dystrybucji zaopatrzenia i znajduje się w raporcie lokalnego urzędnika dla rządu centralnego. Trzej wysłannicy są wymieniani tam jako ważni urzędnicy, podczas gdy dziewczyna Cocachin, chociaż z arystokratycznej rodziny, nie musiała być wymieniona, gdyż nie dotyczyła jej kwestia przydzielanych zapasów. Tym mniej istotnym byłoby wymienianie Polów. Gdyby jednak nie informacja Marko Polo, nigdy byśmy się nie dowiedzieli, w jakiej misji owa trójka została wysłana za granicę. Historia Swiata Rashida al-Dina zawiera krótki opis, jak to Qazan, syn Argona, poślubił Cocachin. Pisze on też, że król spotkał „Khoja [pomyłkowo przetłumaczony jako „urzędnik" w wersji rosyjskiej] oraz grupę posłańców" ${ }^{15}$, potwierdzając stwierdzenie z Opisania Świata, że z trzech wysłanników tylko Coja pozostał przy życiu u końca podróży.

Podsumowując to możemy stwierdzić, że tylko wzmianka w Opisaniu Swiata dostarcza nam jasnego wythumaczenia oficjalnego dokumentu Yongle dadian i stosownego fragmentu z Historii Świata Rashida al-Dina. To dzięki tym zapisom możemy stwierdzić również, że istnieją chińskie źródła odnoszace się do zagadnienia pobytu Marko Polo w Chinach. Dr Wood stwierdza w swej książce, że historia ta została zapożyczona z innego źródła, ale nie może wskazać z jakiego. Podczas gdy faktycznie to te fragmenty sa ogniwami łaczacymi pozornie nie zwiazane zdarzenia z Zhanchi i Histori Swiata dostarczającymi satysfakcjonującego wyjaśnienia dla nich.

Drugim przykładem jest rebelia Wang Zhu, Jest to dobrze znany epizod, który spowodował wielkie zamieszanie w Chinach i został odnotowany w Yuanshi, w zebranych pismach uczonych z okresu dynastii Yuan, jak też w Historii Swiata Rashida al-Dina oraz książce Marko Polo. Ten ostatni twierdził, że był w Chinach w czasie trwania tego buntu. Jest to prawdopodobne, gdyż zdarzenia te rozpoczęły się w nocy, 17 dnia 5 miesiąca w 19 roku okresu panowania cesarza Shizu z dynastii Yuan (16 kwietnia 1282 r.), kiedy Polowie mieli przebywać w Chinach. Chociaż sam Marko Polo nie był świadkiem tych wydarzeń, mógł łatwo uzyskać wiadomości o nich (od cudzoziemców z Regionu Zachodniego lub od Mongołów), gdyż w tym czasie przebywał w Dadu. Dr Wood jest przekonana, że jest to błąd w rachunkach Marko Polo spowodowany ,...prawdopodobnie jego zaufaniem do arabskich i perskich źródeł (...), lub też jakichś perskich przewodników posiadanych przez jego rodzinę" (EW. s. 146). Przyznajemy, że Marko Polo nie był na miejscu zdarzeń, ale nie można zaprzeczyć, że mógł

${ }^{5}$ Rashid al-Din, Historia Świata, tom 3; chińska wersja Stai ji thumaczona z rosyjskiego przez Yu Dajun (Beijing: Commercial Press, 1986), s. 261-262. dowiedzieć się o wydarzeniach później. Relacja Polo, jakkolwiek nie tak pełna i dokładna jak ta w Yuanshi, nie ustępuje wcale opisowi zawartemu w Historii Świata i posiada cechy oryginalności.

Według Marko Polo, Cenchu, który wywołał powstanie, miał pod swymi rozkazami tysiąc ludzi, kiedy jego matka, córka i żona zostały zgwałcone przez Acmata. Doprowadzony do wściekłości postanowił go zabić. Cenchu zmówił się więc z Vanchu, który „był panem dziesięciu tysięcy". Zebral razem swoich ludzi i nocą zabili Acmata.

W przeszłości, zarówno chińscy jak i zagraniczni uczeni byli przekonani, że Vanchu to wymieniany w Yuanshi Wang Zhu, który był „tysięcznikiem". Jednakże Marko Polo wyraźnie stwierdza, że był on „panem nad dziesieccioma tysiacami ludzi", podczas gdy Cenchu „mial pod soba tysiąc ludzi". Chiński tłumacz [dzieła Marko Polo, Feng Chengjin] próbował identyfikować Cenchu z jakimś Chen Zhu, Zhang Ku, Zhang Yi lub Chen Guo. Jednakże nazwisko Chen Zhu, Zhang Ku i Chen Guo nie pojawiają się w Yuanshi $i$ są zwykłą transliteracją. Z kolei postać Zhang Yi pojawia się w prawdzie w Yuanshi, ale nie był on zamieszany w rebelię, a wymowa jego imienia jest zupełnie inna niż Cenchu. Wprawdzie imie Vanchu jest zbliżone w wymowie do Wang Zhu, to ten nie był jednym z głównych spiskowców, lecz jedynie pomniejszym. Wszystko to wprawiało w zakłopotanie komentatorów książki Marko Polo.

Jednak już w 1927 r. brytyjski badacz A. C. Moule wskazywał na to, że Cenchu jest $\mathrm{w}$ istocie transliteracją chińskiego terminu gianhu (człowiek stojący nad tysiącem domostw) i odnoszącym się do Wag Zhu, podczas gdy Vanchu jest transliteracją chińskiego terminu wanhu (człowiek stojący nad dziesięcioma tysiącami gospodarstw domowych), i odnosi się do Gao Heshanga, wspólnika Wang Zhu. Takie wyjaśnienie pokrywa się zasadniczo z opisem zdarzeń zawartym w Yuanshi ${ }^{6}$. Jak jest to zapisane w „Biografii Ahmada" w Yuanshi, Wang Zhu ,wziął brązowy młot $\mathrm{z}$ rąk swojego niewolnika i roztrzaskał nim głowę Ahmada, który zginął na miejscu". Marko Polo w swojej książce pisze natomiast, że Cenchu (gianhu, to jest Wang Zhu) odciął jego głowę mieczem. Chociaż występuje tu różnica broni, rezultat zdarzenia jest - oczywiście - ten sam. Możliwe jest zatem, że Marko Polo tak posłyszał te wieści w Dadu.

Chociaż dr Wood zna studia Moule i Pelliota odnoszące się do identyfikacji Cenchu i Vanchu, to nie traktuje ich ona $z$ należyta powaga i dalej utrzymuje, że nazwisko Wang Zhu ,jest czymś niewyjaśnionym" (ponad-

${ }^{6}$ A. C. Moule, „The Murder of Acmat Bailo," Journal of the Royal Asiatic Society, Hong Kong Branch (Shanghai, 1927). Tekst ten został później włączony do jego książki Quinsai witki Odier Notes on Marco Polo (Cambridge University Press, 1957, s. 79-88). Paul Pelliot, Notes on Marco Polo: „Acmat" na s. 10-11, „Cenchu" na s. 236, i „Vanchu" na s. 870. 
to umieszcza imię Vanchu w nawiasach, zaraz po Wang Zhu). Pisze zaś ponadto, że ,... zamieszanie $\mathrm{z}$ nazwami ludzi i zdarzeń jest prawie niemożliwe do rozwikłania, w szczególności gdy się zważy, iż chińskie źródła sugerują, że Rashid al-Din jest tak samo zdezorientowany jak Marko Polo" (s. 58). Stwierdza ona również, że „Vanchu ... jest opisywany przez Moule'a jako myriarcha (dowódca 10000 żołnierzy), a dla imienia Vanchu istnieje wersja wan $h u$ (chińskie 10000 ludzi). Małym problemem (w porównaniu Z ogólnym zamieszaniem) jest to, że Wang Zhu, jeśli to w rzeczywistości on, zgodnie z chińskimi źródłami, jest nie myriarchq, ale chiliarcha (mogącym powołać tysiąc, a nie dziesięć tysięcy ludzi). Jeśli przyjmiemy, że Vanchu to jego własne nazwisko, to Wang Zhu jest 'znany z udziału w spisku na życie Ahmada ..." (s. 58). Jak z tego wynika dr Wood, tak jak wcześniejszy tłumacz chiński, nadal traktuje Vanchu jako transliterację Wang Zhu. Nic dziwnego, że jest skonfundowana! Konkluduje ona, że Marko Polo prawdopodobnie posługiwał się perskimi i arabskimi źródłami, ponownie cytując koncepcję Franke o możliwym kompilowaniu $\mathrm{z}$ arabskich oraz perskich przewodników (s. 146). (...)

Jednakże wzmianka o tym zdarzeniu w Historii Świata [sławnym dziele Rashida al-Dina] jest dosyć mętna. Jako główny spiskowiec przedstawiany jest tam Gau Finjan (Gao Pingzhang), który był kolega Ahmada, bardzo wobec niego zawistnym. Zabił on Ahmada w zmowie z Han, który udał zmarłego i następnie powrócił do życia ${ }^{7}$. Najwyraźniej Gao Heshang został pomyłkowo wzięty za dwie osoby, a o Wang Zhu nie ma wzmianki. Zatem jest tutaj daleko mniej szczegółów niż w książce Marko Polo. Jest to kolejny dowód na to, że Marko Polo słyszał o tym zdarzeniu od mieszkańców Chin wkrótce po tym wydarzeniu.

Choćby już te dwa fakty, zrelacjonowane przez Marko Polo, dostarczają dostatecznych dowodów dla tezy, że był on rzeczywiście w Chinach. Jego relacja zawiera także wiele innych elementów, które nie wystepuja ani w opisach podróżniczych jemu współczesnych, ani powstałych w zbliżonym okresie. Wiele artykułów i książek poświęconych zostało tej problematyce ${ }^{8}$. Jednak w przekonaniu wątpiących i sceptyków fakty te nie są warte uwagi. Podważają oni wiarygodność Marko Polo również ze

Boyle, The Successors of Genghis Khan, s. 291-292. Op. cit., Rashid al-Din, World History, Vol. 2. s. 344-345.

Znane autorowi opracowania monograficzne to: w języku angielskim - Leonardo Olschki, Marco Polo's Asia (460 stron), Berkeley, 1960.; w języku chińskim takich uczonych jak Yu Shixiong, Zhongshiji daluxingjia Make Boluo [Marko Polo: Wielki Sredniowieczny Podróżnik], Beijing 1988 (łącznie 171 stron); oraz Make Boluo jieshao yи yanjiu [Wstęp do studiów nad Marko Polo] pod redakcją Yu Shixiong, Beijing 1983, (zawierające 37 wartościowych artykułów, łącznie $446 \mathrm{~s}$ ). Istnieje również wiele prac popularnych. względu na sprawy pominięte $\mathrm{w}$ jego opisach, lub sugeruja, te to co zostało trafnie oddane, zostało skopiowane $\mathrm{z}$ innych książek czy przewodników, jednak źródeł takich nie są w stanie wskazać (...).

\section{Problem wersji}

W celu podważenia autentyczności książki Marko Polo, dr Wood podniosła również sprawę występowania różnych jej wersji.

Rzeczywiście mamy do czynienia $\mathrm{z}$ wieloma wersjami przekładów pracy Marko Polo: według Moule i Pelliota, w latach trzydziestych XX w. znane były 143 różne manuskrypty i drukowane wersje tekstu. Dr Wood podaje, że istnieje siedem różnych wersji. „Różnice w ich statusie wynikają z różnorodności języków i dialektów... Daty ich wydania zawierają się w przedziale od 1351 r. do siedemnastego wieku ... Podkreśla się zazwyczaj, że 'oryginalny' rękopis nie zachował się, a żaden z istniejących nie posiada autografu ani Marko Polo, ani spisującego jego relację Rusticello. We wszystkich przypadkach powielania rekopisów wystepuje problem pomyłek kopistów, które mogą być dalej powtarzane, bądź nawet pogłębiane, przy kolejnych przepisywaniach. W przypadku dzieła Marko Polo, dochodzą jeszcze problemy $\mathrm{z}$ przekładem $\mathrm{z}$ jednego języka na drugi oraz $\mathrm{z}$ niezwykłymi, obcymi nazwiskami. To, w połączeniu $\mathrm{z}$ dystansem czasowym pomiędzy zdarzeniami, a ich spisaniem i najwcześniejszą zachowaną wersją, doprowadziło do ogromnych rozbieżności w zawartości 143 z pośród 150 manuskryptów" [s. 43]

Dr Wood cytuje rezultaty komputerowej analizy dwóch naukowców. Jedna analiza „prezentuje krańcowa odmienność stosowanego słownictwa, co wiedzie badacza do wniosku, że być może mamy, co najmniej w jednym rozdziale do czynienia z jeszcze jednym ghost writerem". Kolejny ekspert „dokonał analizy komputerowej wielu fragmentów z różnych wersji i zamiast przyjąć, że Rusticello niekoniecznie był konsekwentny, sugeruje że praca mogła być spisywana przez szereg nieznanych autorów, z których każdy wnosił swoje ulubione słownictwo do pracy" [s. 50] ${ }^{9}$. Dr Wood stwierdza, Że „Trudno jest definitywnie udowodnić autorstwo, gdyż żaden $\mathrm{z}$ analizowanych tekstów nie jest oryginalnym, żaden też nie wyszedł z pod pióra Marko Polo. Dodajac do tego upływ czasu oraz szybko rozwijajaca się wiedze średniowiecznej Europy o Wschodzie, możemy jedynie stwier-

W 4 przypisie rozdziału 7 Dr Wood cytuje M. G. Capuzzo , „La Lingua del Divisarnento del Monde di Marco Polo. 1, Morfologia Verbale", Biblioteca degli Studii Mediolatini e Volgari (serie nuova), (Pisa), vol. V (1980), s. 33. 
dzić, że zachowane wersje zawierają rozmaite interpolacje wprowadzone przez innych do „tekstu podstawowego" który, jak wykazał Benedetto, od dawna zaginął i znany jest jedynie z kopii kopii". [s. 47-48].

Należy stwierdzić, że niektóre z tez dr Wood są możliwe do zaakceptowania i zbliżone do tych głoszonych przez Moule i Pelliota w ich „Wprowadzeniu" do Opisania Świata. Podkreślają oni, że „Problem prawdziwości tekstu książki jest bardzo ciekawy i zawikłany. Książka stawała się popularna... Ale popularność ta była nie tyle rezultatem wierności oryginałowi, ale wynikała właśnie z rozbijania formy, którą pozostawił autor oryginał u, tak, że nie pozostała ostatecznie ani jedna kopia, którą można by uważać za w pełni kompletną czy poprawną. Co więcej, wygląda na to, iż niektóre błędy i pominięcia występują we wszystkich manuskryptach analizowanych do tej pory. Jeśli tak wielka liczba wersji pochodziłaby tylko od jednej kopii, nie będącej oryginałem, ale już błędnej, to jesteśmy faktycznie zmuszeni do wyciągnięcia wniosku, że już sam oryginał musiał zawierać (i pewnie w rzeczywistości zawierał) poważne błędy powstałe w czasie zapisywania, a nie skorygowane potem. Była to w końcu długa i żmudna praca kogoś kto, jak mówi się [po chińsku] „patrzy na wszystko i nie dostrzega niczego". Spisywał to przecież nieprzygotowany Francuz, słabo rozumiejący ponadto włoski dialekt [Marko Polo], jaki czasami był mało zrozumiały nawet dla współczesnych thumaczy. Zatem poczynając od pierwszej kopii każde pominięcie, skrócenie, sparafrazowanie, stwarzało błędy i złe przekłady, pojawiały się również stwierdzenia dopasowane do punktu widzenia „redaktora" i doraźnych zainteresowań czy zamysłów. Ze skutkami tego musimy borykać się do dnia dzisiejszego w blisko 120 tekstach, o których, bez zbytniej przesady można powiedzieć, że nie ma pośród nich dwóch dokładnie takich samych" 10 .

Zarówno Dr Wood, jak i A. C. Moule oraz Paul Pelliot, prezentują podobny punkt widzenia odnośnie braku oryginalnego manuskryptu oraz genezy pomyłek i pominięć w istniejących wersjach. Jednakże rozłożenie akcentów cele sa inne: dr Wood uwypukla interpolacje i uzupełnienia dokonywane przez kopistów późniejszych generacji dla podważenia wiarygodności książki, podczas gdy Moule i Pelliot są przekonani, że wiele błędów i opuszczeń daje się skorygować i poprawić. W rezultacie dr Wood napisała książkę zaprzeczającą, by Marko Polo kiedykolwiek był w Chinach, podczas gdy ci ostatni dokonali nowego syntetycznego opracowania Marco Polo: Description of the World, oraz mistrzowskich Notes on Marco Polo (...)

${ }^{10}$ A. C. Moule and P Pelliot, Marco Polo: The Description of the World, George Routledge and Sons Limited, London 1938, s. 40
Wspomnijmy, że zabójstwo Ahmada pojawia się tylko w przekładzie włoskim dokonanym przez G. B. Ramusio (1485-1557). Jak to już wcześniej stwierdzono, wersja ta wydaje się najbardziej zbliżona do historycznych realiów. Uważna analiza wersji Ramusio dokonana przez profesora Benedetto, włoskiego specjalistę od Marko Polo ujawniła, że „bazuje ona na P (czyli wersji łacińskiej według historyka włoskiego Fr. F. Pippino) z uzupełnieniami $\mathrm{z}$ innych znanych źródeł i z bardzo znacznymi zapożyczeniami $\mathrm{z}$ nieznanego wcześniej ani $\mathrm{w}$ formie rękopiśmiennej ani drukowanej źródła, odkrytego dopiero czternaście lat temu ${ }^{11}$. Moule i Pelliot cytują z G. B. Ramusio następujące stwierdzenie, „Którą to książkę [Marko Polo] zapisaną pierwotnie po łacinie, niezmiernie stara, prawdopodobnie skopiowana $\mathrm{Z}$ oryginału spisanego własnoręcznie przez Marko Polo, często oglądałem i porównywałem $\mathrm{z}$ tą którą obecnie publikujemy, pożyczoną mi przez wielkiego mojego przyjaciela". Cenią oni zatem tę wersję uważając ją ,za jedyny dzisiaj autorytet" odnośnie ,zabójstwa Acmata" ${ }^{12}$

Jednak dr Wood sądzi inaczej. Stwierdza ona: „Wersja Ramusio książki Marko Polo pozostaje jedną z najbardziej barwnych, zawierającą opowieści Marko Polo i jego przesadzone konwersacje oraz romantyczną historię jego powrotu do Wenecji, opowiedzianych $\mathrm{w}$ najlepszym stylu Opowieści z tysiąca $i$ jednej nocy ...Ramusio zamieszcza wiele fragmentów, które są nieznane w żadnej innej ocalałej wersji". „Wersja Ramusio ... jest zadziwiająco pełniejsza i bardziej interesująca od wcześniejszych ocalałych manuskryptów. Wydaje się prawdopodobnym, że włączył on dodatkowe materiały w celu uczynienia tej pracy bardziej interesującą... Nie da się stwierdzić, kto napisał te fragmenty, lecz wydaje się niewiarygodne, że pochodziły one od Marko Polo lub Rusticello. Ramusio prawdopodobnie czuł, że pomoże swojemu bohaterowi czyniąc książkę pełniejszą i bardziej interesującą" [Fal. s. 45-46].

Ze względu na zabójstwo Ahmada, które pojawia się tylko w wersji Ramusio, dr Wood nie mogąc wykazać, że jest to dodatek dokonany przez niego samego, stwierdza tylko ogólnikowo: „Jest to kolejny przykład powtarzanych przez Marko Polo dobrze znanych opowieści" [s. 137]; „... jego zaufanie do perskich i arabskich źródeł ... może również wyjaśniać umieszczanie przez niego opisów zdarzeń których nigdy nie był świadkiem" [s. 146]; czy ,niektóre pomyłki nie mogą być błędami Marko Polo, ale wyraźnie wskazują na wykorzystywanie materiałów z drugiej ręki." [s. 147] (...) Jak stwierdzono powyżej, dokonany przez Marko Polo opis wydarzeń jest jasny i rzetelny, ustępuje jedynie opisom podawanym

\footnotetext{
${ }_{12}^{11}$ Ibid., s. 44-45.
} 
przez chińskie dokumenty historyczne. Marko Polo nie mógł by dostarczyć takich opisów, jeśli by nie był rzeczywiście w Dadu.

Oczywiście książka Marko Polo była przepisywana z pokolenia na pokolenie, co dawało w rezultacie potknięcia pióra, pominięcia i dodatki ${ }^{13}$. Nie zmienia to jednak zasadniczej struktury czy zawartości książki, chociaż obniża jej wartość. Dr Wood i inni sceptycy nie mogą też podać żadnych szczegółów na dowód, że książka zawiera istotnie tylko zapożyczenia z perskich czy arabskich źródeł, lub też przewodników, a opierają to jedynie na przypuszczeniach.

\section{Wyjaśnianie wątpliwości i opuszczeń}

Nie jest rozsądnym oczekiwanie, że opisy podróżne, czy geograficzne, będą zawierały wszystkie wiadomości o danym regionie, tak szczegóły ważne jak nieważne, sprawy istotne i mniej znaczące. Trudno zatem przyjmować to za jedyne kryterium oceny autentyczności pracy. Jednak dr Wood, przejmując zastrzeżenia profesora Franke w tej sprawie, uczyniła dalszy krok i poświęciła cały rozdział sprawom pominiętym przez Marko Polo.

\section{A. SPRAWA PORCELANY}

Marko Polo stwierdził w swojej książce, że lazurowa porcelana wytwarzana była w miejscowości nazywanej Tinglu koło Zaitun (dzisiejsze Quanzhou) w prowincji Fujian i stamtąd eksportowano ją do innych części świata. Jest to wyraźne świadectwo, że Marko Polo widział chińska porcelanę. Dr Wood stwierdza jednak, że „Opis porcelany dokonany przez Marko Polo lokuje jej pochodzenie w prowincji Fujian. Rodzi to szereg kwestii podniesionych przez profesora Pelliota, gdyż Marko Polo lokuje jej produkcję w tajemniczo nazwanym mieście Tingiu (czy Linigui). Opisuje on przygotowywanie gliny i stwierdza, że jest ona 'lazurowa' oraz

Dr. Wood przytacza pokonanie Togta przez Nogaja jako przykład i stwierdza, że opis powstał dopiero w piętnastym wieku w wersji z Toledo (to jest wersji Z). „Według Rashida, bitwa ta miała miejsce w 1298-99 r. i dlatego nie mogła być znana ani Marko Polo ani Rusticello w czasie spisywania [zaginionego] oryginału. Musi to być zatem późniejsza wstawka do tekstu. Uwaga autora: bitwa ta znana jest nie tylko z wersji „Z", lecz również z innych, choć mniej szczegółowych wersji (...) Jednym słowem nie ma znaczenia czy ten paragraf został dodany osobiście przez Marko Polo, czy przez kogoś innego, jest on odosobnionym przykładem wykorzystanie perskich relacji i nie może stanowić dowodu na to, że Marko Polo nie był w Chinach 'szklista'. Problemy z lokalizacją pieców wynikają z określenia koloru. Pelliot traktuje 'accuri > jako „lazurowy" i identyfikuje go z zielonym celadonem, który był powszechnie produkowany w owym czasie na południu Chin. Taka identyfikacja czyni problem znalezienia miasta, gdzie ją produkowano bardziej złożoną, gdyż żadna $\mathrm{z}$ miejscowości, gdzie wytwarzano celadon nie jest zbliżona z nazwy do Tinqiu" [W F. s. 65-66].

Dr Wood dalej jednak stwierdza: „Jest zaskakujące, że herbata, porcelana i krępowanie stóp, trzy rzeczy symbolizujące Chiny w zachodnich wyobrażeniach, są zupełnie nieobecne w jakże popularnym tekście" [s. 75] (...).

\section{B. PROBLEM DRUKU}

Dr Wood stwierdza, że Marko Polo informuje o papierowych pieniądzach, ale nie o druku. Pisze również, że we fragmencie poświęconym omówieniu obyczajów w Kinsai (obecne Hangzhou), iż „Opisanie Świata zawiera wprawdzie wzmianki o wykorzystywaniu podobizn ludzi, o koniach i wielbłądach $\mathrm{w}$ zaprzęgu $\mathrm{z}$ chomątem, paleniu $\mathrm{w}$ czasie pogrzebów papierowych pieniędzy, to szeroko rozpowszechniony druk metodą drzeworytniczą ... nie jest wspomniany" [s. 71-71].

Marko Polo często wspomina papierowe pieniądze, a skoro takie pieniądze powstają' $\mathrm{w}$ procesie druku, to zapewne o nim wiedział. Był on przecież synem kupca, i jak zauważa w swojej książce dr Wood jego oko kupca bardziej było wyczulone na rzadkie, luksusowe i kosztowne dobra niż zwykłego obserwatora. $\mathrm{Z}$ tego powodu zainteresował się papierowymi pieniędzmi, na które misjonarz Wiliamm Rubruk nawet nie zwrócił uwagi [ $s$. 64]. Skoro jednak w Europie nie znano techniki druku ani materiałów drukarskich, nie mógł użyć słowa „druk", [a trudno mieć doń pretensje, iż nie opisuje samej techniki].

\section{KWESTIA PISMA CHIŃSKIEGO}

Dr Wood stwierdza, że misjonarz Rubruk w dziele The Journey of William of Rubruck, zamieszcza opis pisma chińskiego, podczas gdy praca Marko Polo nie zawiera o nim wzmianki. Brak jakichkolwiek odniesień do tego, jakże odmiennego pisma, w Opisaniu Świata został objaśniony przez Leonardo Olschki, który przypuszcza, że język był zbyt niedostępny dla Marko Polo jako „obcokrajowca nie wykazującego żadnych zainteresowań literatura ani sprawami ducha". Jednak dr Wood odrzuca to thumaczenie. „Jest trudnym do przyjęcia pogląd - pisze ona - że w kraju, w którym wynaleziono papier, a słowo pisane znaczyło więcej niż gdziekolwiek indziej, ktoś, nawet obcokrajowiec, mógł twierdzić, że służył w administracji państwowej, ale ani nie odnotował mongolskiego, czy chińskiego, systemu pisma, ani też nie poświęcił im najmniejszej uwagi" [s. 69-70]. 
Dr Wood nie zna, najwidoczniej, źródeł odnoszących się do tej kwestii. Zgodnie z „Biografią Cui Bina", rozdziału w Yuanshi, w piętnastym roku panowania Zhiyuan (1278 r.) nie było w prowincjach regionu Jangcy i Huai ani jednego urzędnika [odnosi się to do Mongołów i przybyszów z Azji Centralnej, nazywanych „ludźmi z krain zachodnich", albo inaczej zwartych sercu, jakim powierzano funkcje administracyjne w podbitych Chinach] znającego pismo chińskie. Ye Ziqi, członek rodu panującego, ze schyłkowego okresu dynastii Yuan, który opanował to pismo, w swoich „Zapisach różnych", rozdziale z Dziet zebranych Ye Ziqi, daje nawet opis bardziej szczegółowy: „Ludzie z północy [to jest Mongołowie oraz ich sojusznicy] byli niepiśmienni, chociaż powierzano im wysokie stanowiska. Kiedy pisali rozporządzenia i podpisywali dokumenty, często popełniali głupie pomyłki. Pisząc znak qi (siedem), jeden $\mathrm{z}$ nich pociągnął, na przykład, kreskę poziomą w lewo, zamiast na prawo, zdeformowawszy ten znak tak, że ktokolwiek to widział nie mógł powstrzymać się od śmiechu. Oczywiście, niektórzy z nich byli piśmienni, ale takich było niewielu. Dlatego urzędnikom państwowym różnych szczebli przydzielano tłumaczy i pisarzy. Byli zatem zatrudnian thumacze mongolscy i arabscy, którzy obsługiwali funkcjonariuszy z regionów zachodnich. W języku mongolskim tłumacz zwany był qielimachi".

Dlatego też było możliwe angażowanie cudzoziemców do różnych przedsięwzięć, nawet jeśli nie mówili oni po chińsku, czy nie znali tego pisma. Jest zaś zupełnie irracjonalnym wyciąganie wniosków odnośnie Marko Polo na podstawie spostrzeżeń Rubruka, gdyż ten ostatni był wykształconym mnichem katolickim, patrzącym na różne sprawy $\mathrm{z}$ zupełnie odmiennej perspektywy. Nie tylko opisał on samo pismo chińskie, ale również odnotował istnienie pisma tybetańskiego, tanguckiego oraz ujgurskiego. Marko Polo zaś, jako kupiec, zainteresowany był przede wszystkim miejscowymi produktami, ich wytwarzaniem i handlem, jak też egzotycznymi obyczajami. Ze względu na braki swego wykształcenia, trudno mu było czytelnie przedstawić obce pismo chińskie, chociaż musiał widzieć znaki chińskie, choćby wydrukowane na banknotach, o których pisze.

\section{SPRAWA HERBATY}

Brak najmniejszej wzmianki o herbacie dostarcza dr Wood dalszych argumentów dla piętrzenia jej waţpliwości. „Tak piękne miasta jak Hangzhou Suzhou miały bardzo wiele wszelkiego rodzaju herbaciarni ... Marko Polo z całą pewnością powinien był gościć w jednej z nich... Trudno wręcz sobie wyobrazić jego siedemnastoletnie przebywanie w Chinach bez odnotowania popularności tego napoju" [s. 71-72].

Odnotowując to pominięcie profesor Franke wyjaśnia je następująco: „Nigdy nie wspomina on herbaty, lecz może to być związane z tym, że po prostu sam jej nie lubił, lub też z brakiem zwyczaju częstowania nią gości przez Mongołów [wśród których się obracał]" (...) L. Olschki sądzi, że powodem pominięcia przez Marko Polo wzmianki o herbacie jest „,powstrzymywanie się przez niego od podawania szczegółów, które nie mogły by być zrozumiane $\mathrm{i}$ docenione przez jego rodaków i współczesnych" ${ }^{14}(\ldots)$ Według innego wyjaśnienia, Marko Polo nie wspomniał o chińskiej herbacie dlatego, że trzymał się prawdopodobnie własnych zwyczajów i nie pił jej. W owym czasie Mongołowie i ludzie z „krajów zachodnich" również jej nie lubili. Marko Polo był zaś związany głównie z nimi, a tylko sporadycznie kontaktował się z Chińczykami, co wyjaśnia, dlaczego nie wspomina o tym chińskim zwyczaju ${ }^{15}$ (...) Profesor Huang Shijian opublikował artykuł zatytułowany „O początkach rozpowszechniania się herbaty w Azji Północnej i Regionie Zachodnim"16, w jakim wspiera moją argumentację dalszymi szczegółami.

\section{E. ZWYCZAJ KREPOWANIA STÓP ${ }^{17}$}

Dr Wood wskazuje na trudne do zrozumienia pominięcie przez Marko Polo nader specyficznego zwyczaju chińskiego krępowania stóp kobiet [by miały je jak najmniejsze], podczas gdy podróżujący później franciszkanin Odoryk z Pordenone opisał go w odniesieniu do Chin Południowych (...) Uzupełnia to krótka historia tego zwyczaju w Chinach. Przypomina, że krępowanie stóp stało się popularne pośród klas wyższych w okresie dynastii Song (960-1279). Ostatecznie, praktyka ta stała się nieomal powszechną, $\mathrm{Z}$ wyjątkiem najbiedniejszych wieśniaków, którzy potrzebowali w pełni sprawnych kobiet do pracy w polu. Jednakże Mandżurowie, którzy panowali w Chinach od 1644 aż do 1911 r., nigdy nie przejęli tego zwyczaju, podobnie jak nie uczynili tego wcześniej Mongołowie. Po czym stwierdza: „Można również argumentować, że zamykanie kobiet w kręgu domowym mogło spowodować, iż Marko Polo mógł widzieć zaledwie kilka chińskich kobiet $\mathrm{z}$ wyższych klas. Nie jest zapewne przypadkiem, że opisuje on żony kupców, gdyż ci ostatni byli tradycyjnie pogardzani, a ich synowie mieli zamknięty dostęp do klasy urzędniczej ... zatem ich żony

I. Olschki porusza to zagadnienie wielokrotnie w swojej Marco Polo's Asia. Stwierdza on, że mnich Odoryk również nie informuje o herbacie, prawdopodobnie dlatego, że Mongołowie jej nie lubili.

${ }^{15}$ Patrz cytowany zbiór studiów pod redakcją Yu Shixionga.

${ }^{16}$ B Histarical Research, 1993, no. 1.

${ }_{17}^{17}$ B Histarical Research, 1993, no. 1. wano normalny rozwój kości, zaś stopa formowała się w rodzaj kopytka, albo też podwijała Powodowało to ogromny ból i skazywało kobietę na kusztykanie z trudem cale życie. Obyczaju tego zakazano po Rewolucji Xinhai (1911 r.), ale praktykowano go niekiedy jeszcze do II wojny światowej (red.) 
mniej były podatne na przyjmowanie tego zwyczaju klas wyższych, mogły również chętniej paradować po ulicach demonstrując swoje bogactwa, gdzie cudzoziemiec mógł je oglądać. ...Jest zatem dość prawdopodobne, że w późniejszych latach panowania Mongołów, Marko Polo mógł wciąż widywać kobiety z nieskrępowanymi stopami na ulicach chińskich miast" [s. 72-73].

Dalej jednak kontynuuje: „Tym nie mniej, mnich Odoryk z Porderone, który podróżować po Chinach od 1320 r., a podyktował swoje wspomnienia w 1330 r., opisuje krępowanie stóp w Południowych Chinach ... Nie wydaje się prawdopodobne, by obyczaje mogły zmienić się tak raptownie w przeciągu zaledwie pięćdziesięciu lat. Uderza zatem, iż Marko Polo nie dostrzegł krępowania stóp, podczas gdy pobożny mnich Odoryk, który nie miał dostępu do klas wyższych, inaczej niż sławny Wenecjanin, opisał je ze szczegółami" [s. 73-74].

Mamy tak wiele relacji i monografii o krepowaniu stóp, że nie ma potrzeby, by rozwodzić się nad tym. Przypomnimy tylko w skrócie, że zwyczaj ten pojawił się za panowania cesarza Shenzonga (1068-1085) z Północnej Dynastii Song i rozprzestrzenił się z północy na południe w czasach Południowej Dynastii Song (1127-1279), jakkolwiek ciągle ograniczało się to do wyższych sfer i wielkich miast. W czasach dynastii Yuan (1206-1368), kobiety na południu Chin również poddały się temu zwyczajowi i „czuty się zażenowane, jeśli ich stopy nie były obwiązane" ${ }^{18}$. Jednakże w czasie gdy Północne Chiny znajdowały się pod panowaniem dynastii Liao (907-1125), Jin (1115-1237) i Yuan, Kitanki, Dżurdżenki i Mongołki [należące do grup etnicznych panujących kolejno w tej części Chin] nie krępowały swoich stóp, a brak zachęty do tych praktyk ze strony panujacych musiał mieć pewien wpływ na społeczeństwo. Według Zhang Xinglanga, władcy z dynastii Liao, Jin i Yuan gardzili Tymi zwyczajami etnicznych Chińczyków (Hanów).

W czasach Południowej Dynastii Song, większość ludności terenów leżących na północ od rzeki Huai przyjęła nazwiska, stroje i język owych rzadzacych mniejszości etnicznych z północy. Nie jest zatem trudno sobie wyobrazić, że krępowanie stóp nie było wówczas w modzie w Chinach Północnych. Marko Polo spędził wprawdzie w Chinach siedemnaście lat, ale głównie przebywał na północy. Ogromna większość szczegółowych opisów w jego książce odnosi się zatem do zdarzeń i spraw dotyczących Północy. Marko Polo nie odnotował krępowania stóp zapewne również z tego

${ }^{18}$ Tao Zongyi (przełom epoki Yuan i Ming), Chuogeng lu, juan 10; Monogrfie o krepowaniu stóp: Yao Lingxi, Caifei lu [Porady dla kobiet chcących posiadać najmniejsze stopy], Tianjin:1938 (Tianjin Bookstore Company); Gao Hongxing, Chan = shi [Historia krępowania stóp], Shanghai 1995 (Shanghai Literatura and Art Publishing House). powodu, iż rzadko widywał kobiety pochodzące $\mathrm{z}$ rodzin $\mathrm{z}$ wyższych sfer $\mathrm{w}$ okresie, gdy urzędował na południu, albo też miał za mało czasu na obserwacje.

Mnich Odoryk z Porderone widział kobiety z bandażowanymi stopami w Hangzhou w Chinach Południowych w czasie panowania cesarza Taidingdi", i pisał później w swoich Cathay and the way Thither, że w oczach Chińczyka kobiety krępujące stopy wydają się piękniejsze ${ }^{2 \circ}$. Słowa te wymagają komentarza. Odoryk mógł widzieć takie kobiety, gdyż prawdopodobnie: 7: );,Przybył do Guangzhou morzem, skąd udał się do Quanzhou i Fuzhou w prowincji Fujian i dalej do Hangzhou i Nanjingu, by ostatecznie podróżując Wielkim Kanałem dotrzeć przez Yangzhou do [stolicy] Dadu. Przebywał zatem dostatecznie długo w południowej części Chin; 2) Odnotował on, że będąc w Hangzhou pytał tamtejszych chrześcijan, saracenów [to jest muzułmanów], jak też „,pogan" o miasto. Czterech tubylców z miejscowych sekt zaprowadziło go z wizytą do buddyjskiej światyni. Prawdopodobnie od nich to usłyszał o zwyczaju krepowania stóp w Chinach lub nawet widział go na własne oczy. Stwierdził on bowiem, że „przekroczył pałacowy mur pewnego mieszczanina", który oczekiwał w towarzystwie pięćdziesięciu służebnych. Po czym natychmiast zamieszcza opis jego długich paznokci będących wyznacznikiem szlachetnego pochodzenia i kobiet pyszniących się swoimi małymi, skrępowanymi stopami".

Z opisu jego podróży możemy wnosić, że Odoryk dotarł do wielu miejscowości, w tym centrów handlowych i produkcyjnych, jednak podaje niewiele opisów kwitnących przedsiębiorstw i handlu. Pisząc o Chinach Południowych, stwierdza ogólnikowo, Że tamtejsi mieszkańcy są głównie rzemieślnikami i przedsiębiorcami. W Guangzhou (nazywanym w jego książce „Censcalan") zauważa pogan, olbrzymie statki, wielkie gęsi i węże służące za pożywienie. Tym, co przyciągnęło jego wzrok w Quanzhou, był kościół chrześcijański, „poganie" i różnorodność rzeczy codziennego użytku, w szczególności cukier [nieznany wówczas w Europie]. W Fuzhou zwrócił uwagę na koguty, bezpióre kury i ,ptaki wodne używane do połowu ryb" (kormorany). W Hangzhou (Casay), o którym pisze jako o największym mieście świata, odnotowuje on jedynie ogromną liczebność ludności, wielość mostów, jak również obecność chrześcijan, saracenów i „pogan" [tak zapewne określał Chińczyków wyznających buddyzm i praktykujących kulty miejscowe] (...) W Yangzhou czyni wzmiankę o kościele nesto\#4,ńskim, chrześcijanach i dochodach z soli, a na placu nazywanym

\footnotetext{
${ }^{19}$ Panowat on w latach 1324-1328 (red.).

${ }^{20}$ Introduction to The Deseription of the World, s. 242

${ }^{21}$ Fitiar Odoric, Cathay and the Way Thither, Vol. 2 (translated by Hemy Yule)
} 
Sunzumatu zauważył ogromną skalę handlu jedwabiem oraz innymi artykułami. Przebywał on w Dadu trzy lata i sześć rozdziałów swojej książki poświęca opisaniu stolicy Yuan. Jednakże opisuje on jedynie pałac Wielkiego Chana, jego życie oraz pozycję zajmowaną przez chrześcijan na dworze, nie wspomina natomiast nawet słowem o przemyśle czy handlu w stolicy ${ }^{22}$.

Kontrast z relacjami Marko Polo jest zatem ogromny, gdyż ten gdziekolwiek przebyWał, przede wszystkim odnotowywał aktywność produkcyjna handlowa (...). Z Cianglu opisał produkcje soli, prowadzona na wielką skalę w tym mieście. Dalej zaś kontynuował: „Ciangli jest miastem ... o pięć dni drogi od Cianglu, w ciągu tych pięciu dni drogi mija się wiele wiosek i mias ... Sa to ziemie przynoszace swoim panom dochód płynący w większości z wielkiego handlu i rzemiosła". Zauważył on również na ogromnej rzece „wiele statków, które płyną załadowane wielką ilością rozmaitych produktów, zarówno z prądem jak i pod prąd". „Kiedy ktoś wyruszy z Ciangli w tę sześciodniową podróż zawsze znajdzie miasta

i wioski odpowiednie do handlu o znacznej wartości, ważności i aktywności, w jakich ludzie ... żyja $\mathrm{z}$ handlu i rzemioser ${ }^{23}$. Zbyt wiele jest podobnych przykładów, by je tutaj wymieniać. Wszystkie wymienione powyżej miasta znajdują się jednak w północnej części Chin. Jego opisy przemysłu

i handlu w najbardziej rozwiniętych miast południa, takich jak Quanzhou, Fuzhou i Hangzhou, w których również przebywał Odoryk, są bardziej emocjonalne i podają więcej szczegółów (...).

Każdy z tych podróżników obserwował i opisywał kraj z odmiennej perspektywy $\mathrm{W}$ rezultacie ich opisy podróży odnoszące się do tych samych miejsc zawsze różnią się, zarówno w sprawach ogólnych jak i szczegółach. Jes zatem bezpodstawne i nielogiczne wykorzystywanie prac jednego autora, jako pewnego standardu i krytykowanie innego za pominięcia, lub deklarowanie wręcz, że praca jego zawiera tylko zapożyczenia z innych źródeł (...)

\section{Problem Wielkiego Muru}

Dr Wood poświęca cały rozdział kwestii braku jakiejkolwiek wzmianki u Marko Polo o Wielkim Murze W rozdziale 11 ironicznie stwierdza, że „przegapił on największy mur [światar [s. 96-101]. „Już na pierwszy rzut

\footnotetext{
22 Ibid., $s .178-204$ i 209-240.
}

${ }^{23}$ A. C. MouleandP. Pelliot, MarcoPolo: The Description of the World, ss. 298, 301 i 302. J. oka pominięcie to jest uderzajace, lecz zagadnienie jest o wiele bardzie skomplikowane ze względu na kwestię: jak Wielki Mur mógł wyglądać w trzynastym wieku i jak wiele $\mathrm{z}$ niego istniało w owym czasie". Dotyka ona zatem kluczowej sprawy, stwierdzając, że ,aż do czasów dynastii Ming (13681644) ... ta część Muru ... nie była oblicowana cegłą ..." O jego wcześniejszym stanie pisze zaś: „Mur był prawdopodobnie zbudowany głównie z ziemi ... wsypywanej pomiędzy szalunki z desek i ubijanej warstwami, co pozwalało tworzyć zadziwiająco długotrwałe mury i platformy". Cytuje również ona za Wtasnymi spostrzeżeniami Georga Leonarda Stautona, sekretarza lorda Macartneya, który przybył ze swym poselstwem do Chin w 58 roku panowania cesarza Qianlonga (1793) i po odwiedzeniu Wielkiego Muru napisał „Pierwszy Europejczyk, który opublikował jakiekolwiek informacje o tym cesarstwie, Marko Polo, nie dał nawet wzmianki o Wielkim Murze; ... To przemilczenie nasuwa pewne wątpliwości ... czy mur ten rzeczywiście istniał w trzynastym wieku".

Jednakże Staunton natychmiast podejmuje próbę wyjaśnienia tego ,przemilczenia" Marko Polo, sugerując, że mogła być to pomyłka edytorska, którą zostałaby zapewne sprostowana, gdyby „dał on światu pełne sprawozdanie ze swojej podróży natychmiast po powrocie, zamiast dyktować niepowiazane fragmenty w wiele lat po nim, w miejscu odległym od domu, pozbawiony najprawdopodobniej swoich notatek czynionych $\mathrm{w}$ podróży oraz innych oryginalnych zapisków" (...)

Dr Wood cytuje wprawdzie studium Arthura N. Waldrona „Problem Wielkiego Muru" ${ }^{24}$, w jakim stwierdza, że mógł on popaść w taki stan dewastacji między panowaniem dynastii Qin [221-206 r. p. n. e., która go zbudowała] a epoką Ming, iż prawie całkowicie zaniknął. Kontynuuje ona jednak swe rozważania następujaco: „Oczywistym jest, że tak charakterystyczna dziś, licowana kamieniem część muru położona na północ i północny wschód od Pekinu, zostały wykonane dopiero po podróży Polów na Wschód. Większość Muru była i nadal jest wykonana po prostu $z$ lessu. Ziemne części nadal rzucają się w oczy w czasie podróży koleją z Xranu do Dunhuangu. Poza tym stan zachowania miejskich wałów ziemnych w Chinach jest zazwyczaj nadzwyczajny: fragmenty muru dynastycznego stolicy Shangów [z II tysiąclecia p.n.e.] ciągle są widoczne w Zhengzhou

W trzynastym wieku Musiała być zachowanych znacznie więcej odcinków Wielkiego Muru, choć wykonanego z ubitej ziemi, tak że bardzo trudno było by podróżując do Chin z zachodu nie zauważyć ich [s. 101].

$\mathrm{Na}$ temat Wielkiego Muru prowadzono wiole badań, istnieją również nader liczne wzmianki o nim w Chinach. W okresie Wiosen i Jesieni oraz

\footnotetext{
${ }^{24}$ Harvard Journalof AsiaticStudies, Vol. 43 (1983), nr 2.
} 
Królestw Walczacych, zanim jeszcze Pierwszy Cesarz dynastii Qin wybudował Wielki Mur, udzielne księstwa wznosiły mury na swych granicach dla obrony przed wrogami. Po okresie Qin wszystkie dynastie, za wyjątkiem Tang, Północnej Song, Liao i Yuan, przyczyniały się do budowy muru. Jednakże mur, który stoi do dziś porażając ogromem, został wybudowany dopiero za panowania dynastii Ming (...)

Dr Wood stwierdza wprawdzie, że ziemne sekcje muru wciąż są widoczne $z$ okien pociągu na trasie Xi'an Dunhuang. Jednakże trzeba zwrócić uwagę na dwa aspekty. Po pierwsze, podróżni mogą zazwyczaj dostrzec jedynie wysokie wieże wartownicze wybudowane wzdłuż muru w starożytności w celu obserwacji i obrony. Wiele z nich zostało odkrytych przez brytyjskiego archeologa Aurela Steina opodal Dunhuangu. Co zaś jeszcze istotniejsze, podróżni moga zauważyć zarówno te wieże, jak i odcinki ziemnego muru jedynie dlatego, że posiadają specyficzną wiedzę historyczna [i wiedza o jego istnieniu]. Aurel Stein odkrył nie tylko wieże, ale przybył on do Chin jako archeolog dla prowadzenia badań naukowych. „Po usunięciu wierzchniej warstwy nawianego piasku ... dotarł do regularnego muru zbudowanego z poziomych pęków trzciny umieszczanej w regularnych odstępach w warstwach ubitej gliny" ${ }^{25}$. Nie zaskakuje, że dr Wood była w stanie dostrzec ruiny Wielkiego Muru, które zostałyby zapewne przeoczone przez zwykłych ludzi, gdyż studiowała problem Marko Polo i rozglądała się uważnie za Wielkim Murem.

Sprawa ta wyglądała jednak zupełnie inaczej z perspektywy Marko Polo. Był on synem kupca, miał skape wykształcenie i nic nie wiedział na temat historii Chin. Jak można więc oczekiwać od niego, by zainteresował się jakimiś zrujnowanymi kawałkami muru i wież strażniczych oraz opowiadał o ich istnieniu innym?

W książce Marko Polo nie ma nawet wzmianki o „Wielkim Murze" zbudowanym przez dynastię Jin, niedługo przed jego przybyciem do Chin. Wang Guowei, uczony starszego pokolenia, podał jego szczegółowy opis w artykule „Graniczne rowy z epoki dynastii Jin" ${ }^{26}$. Stwierdza tam, że w dokumentach historycznych z okresu Jin nie ma wzmianek o „Wielkim Murze", a jedynie o „granicznych wieżach strażniczych" oraz „granicznych rowach". Te ostatnie stanowiły „rowy kopane wzdłuż granicy w celu powstrzymywania ruchu konnicy przeciwnika," podczas gdy te pierwsze związane były z „fortyfikacjami wznoszonymi w strategicznych punktach dla zakwaterowania żołnierzy strzegących granicy". Fortyfikacje te budowano dla obrony przed nadgranicznymi plemionami, w szczególności Mongołami. Pozostałości tych rowów i wartowni istniały oczywiście jesz-

${ }^{25}$ Aurel Stein, On Ancient Central-Asian Tracks, s. 165-169.

${ }^{26}$ Wang Guowei, Dzieła zebrane Wang Guoweia (w jęz. chińskim), juan 15. cze w czasie dynastii Yuan. Zgodnie $\mathrm{z}$ informacjami zgromadzonymi przez Wang Guoweia, Qiu Chuji (Nieśmiertelny z Changchun), Zhang Dehu oraz Wang Yun, którzy żyli odpowiednio w czasach Czyngis Chana, zanim cesarz Shizu [to jest Kubilaj-chan] z dynastii Yuan wstąpił na tron oraz podczas jego panowania, odwiedzili ruiny tych fortyfikacji i pozostawili tam swoje znaki. Marko Polo często podróżował pomiędzy Dadu (dzisiejszym Pekinem) i Shangdu (dzisiejszym Zhenglangqi w Mongolii Wewnętrznej) i oczywiście musiał mijać te ruiny oraz rowy, ale nie wzbudziły one jego zainteresowania. Jest to nawet dość oczywiste. Trzej wymienieni powyżej uczeni wiedzieli o tych fortyfikacjach i znali historię dynastii Jin, zatem ruiny te wzbudzały ich zainteresowanie, w przeciwieństwie do Marko Polo. Ponadto rowy te i wieże strażnicze od dawna były opuszczone, i jako ruiny nie były interesujące dla przeciętnych podróżnych, nie wzbudziły też ciekawości Marko Polo. Biorąc zatem pod uwagę zarówno czynniki obiektywne jak i subiektywne, jest najzupełniej normalne, że Marko Polo nie wspomniał o Wielkim Murze (...)

\section{Analiza „Wniosków" i komentarz}

W ostatnim rozdziale swej książki „Wnioski", dr Wood przedstawia końcowe oceny Marko Polo i jego książki, a ponieważ czyni to zwięźle, warto zapoznać się z jej punktem widzenia (...).

Przede wszystkim wskazuje ona, iż książka Marko Polo „nie jest prezentacją marszruty czy prostą relacją z podróży" (...) „Toteż choć rozmaite wyprawy starały się podążać 'śladami Marko Polo', to ... znakomici podróżnicy ... stwierdzali, że nie jest obecnie możliwe podążanie za nim krok po kroku poza Persję". Niektóre miejsca są tak mylące, że sir Henry Yule, komentator książki Marko Polo, stanął przed ogromnymi problemami i trudnościami [chcąc wyznaczyć jego marszrutę]. Dr Wood uważa również za zaskakujące, że poza Prologiem są tylko nieliczne odniesienia do samych Polo. Zgodnie z jej danymi, jest ich tylko osiemnaście w całej książce (nie wliczając Prologu). Stwierdza ona, że książka ma „bezosobowy ton z silnym akcentem przewodnika" i jest zatem bardziej pracą geograficzną czy historyczną niż osobistymi relacjami z widzianych rzeczy.

Prawda jest, że istnieja pewne przekrecenia i niejasności w informacjach o marszrucie Marko Polo, ale ciągle jest to droga której można się trzymać. Wzmiankowane trudności Yule dotyczyły jedynie podróży na trasie z Yongchang do birmańskiej stolicy i pomiedzy Birma a Laosem, poza tymi szlakami, żadne inne większe trudności nie wystąpiły, co wynika z marszrut zaplanowanych przez Yule na podstawie informacji Marko Polo. 
Stwierdzenie, że „tylko 18 wzmianek odnosi sie do Marko Polo i jego rodziny" jest nawet jeszcze trudniejsze do zrozumienia: wyrażenia ,ja" i „my", odnoszące się nie do kogo innego jak tylko do Marko Polo i jego rodziny, pojawiają się w książce mnóstwo razy (...).

Stawia ona tezę, że książka Marko Polo nie jest relacją z podróży i „spełnia raczej obietnice z karty tytułowej „'opisanie świata' poza Wenecją". Dr Wood sugeruje; że „Jednym z bodźców to tej kompilacji mogło być trochę jeszcze przedwczesne poczucie wzrastającego zapotrzebowania na geografie w końcu trzynastego i na poczatku czternastego wieku". Podaje ona, że Jacopo da Acqui, Vincent z Beauvais oraz sir John Mandeville tworzyli kompilowane historie i geografie świata ${ }^{27}$. Rashid al-Din również napisa Histerie Świata [Jauri-ut-Tawaruh (Zbiór Historii)] po arabsku. Dr Wood przypomina, że książkę Mandevilla powitano $\mathrm{z}$ wielkim entuzjazmem i przetłumaczono na wiele europejskich języków, lecz ostatecznie okazało się, że była falsyfikatem, w którym połączono wiele fragmentów z co najmniej piętnastu źródeł. Konkluduje zatem: „Z natury swojej będące zapisem z drugiej ręki Opisanie Swiata, spisane przez Rusticello z informacji podanych przez Marko Polo, wraz z dodaniem jeszcze innych przez późniejszych tłumaczy, mogło łatwiej skrywać każde oczywiste zapożyczenie. Gdy gwiazda Mandevilla zgasła, Marko Polo zaczął się cieszyć pośmiertną sławą, która zaczęła rozkwitać" (...).

Wskazuje ona również, że brak spójnej marszruty w Opisaniu Świata może być efektem entuzjazmu przy tej pracy pisujacego romanse Rusticello, który mógł dążyć do rozbudowania jej poza opis podróży, w rodzaj obszernej historii świata, $\mathrm{z}$ włączeniem opisów nie związanych $\mathrm{z}$ tematem takich krajów, jak Rosja czy Japonia oraz starożytnych bitew (... ) „Przed rozpowszechnieniem się druku i praw autorskich, kontynuuje ona, trudno jest sobie wyobrazić zdobycie fortuny przez napisanie czegoś. Jednakże Rusticello, który uprzednio korzystał dzięki swym literackim talentom z łaskawości następcy angielskiego tronu ${ }^{28}$, mógł dążyć do podobnych łask". Warto zwrócić uwage jak wiele tu przypuszczeń, słów „możliwe", „być może" i ,prawdopodobnie".

Jacopo da Acqui był współczesnym Marko Polo, jego praca geograficzna, Imago Mundi, zawiera opis powrotu Marko Polo, jego ojca i wuja z Mongolii, jego uwięzienia w wojnie z Genuą oraz relacji z tego, co on widział i słyszał w podróży; Vincent de Beauvais (1190-1264), Specutum Historiae, historia świata poczawszy od stworzenia świata do wieku trzynastego napisana w 1244; Sir John Mandeville był brytyjskim pisarzem; twierdzi on, że napisał swoje Travels po podróży dookola świata.

${ }^{28}$ Wiązało się to z uzyskaniem przezeń od księcia Edwarda rękopisu Opowieści Okra głego Stołu, znanych już wcześniej lecz trudnych do uzyskania. Rusticello wykorzysta fragmnety z nich włączając je do nowej książki Meliadus. Patrz: Henry Yule, Cathay and the Way Thither, Vol. 1, s. 58-60.
Następnie dr Wood przedstawia swój punkt widzenia na pochodzenie źródeł i materiałów do Opisania Świata, Jakkolwiek podkreśla, że istnieje wiele problemów do rozwikłania, przedstawia następujące sugestie: 1) Jeśli by ocalały rodzinne papiery, mogły by one zawierać materiały związane $\mathrm{z}$ rodzinnymi szlakami handlowymi na wschód i, być może, perskie przewodniki dla kupców. Mogły tam być również perskie prace historyczne zawierające informacje o starożytnych bitwach oraz opisy Rosji i Japonii, które leżały poza obszarem osobistych doświadczeń rodziny Marko Polo. 2) Inne źródła, wliczając w to dawne arabskie opisy Chin, takie jak anonimowe Opisanie Chin i Indii z 851, Rashida alDina Historię świata z początku czternastego wieku, czy zapiski z podróży Ibn Battuty $\mathrm{z}$ połowy czternastego wieku ${ }^{29}$, z powodu występowania dużych podobieństw pomiędzy książką Marko Polo, a tymi trzema tekstami (...) Ciągnie ona, „Chociaż wielu poszukiwało tego rodzaju przewodników, to na nieszczęście trzynasty wiek należy do 'Czarnego wieku popularnej literatury perskiej' i żadna tego rodzaju książka nie została odnaleziona".

Skoro dr Wood utrzymuje, że książka Marko Polo zawiera materiały pochodzace raczej z drugiej ręki niż z bezpośrednich obserwacji, to logicznym jest, że Marko Polo nie odwiedził Chin. W związku z tym pojawia się pytanie, gdzie spędził wszystkie te lata? Przyjrzyjmy się co dr Wood ma na ten temat do powiedzenia.

„Jeśli Marko Polo nie był w Chinach — jak pisze — to, niestety, nic nie wskazuje na to, że był gdziekolwiek indziej". Wysuwa ona swój własny pomysł: „Pierwsza podróż na wschód odbyta przez ojca i stryja Marko Polo oraz ich spotkanie $\mathrm{z}$ ważną osobistością przedstawione w Prologu mogą być jedynym konkretnym śladem. Istnienie ,zezwolenia na przejazd" na złotej płytce jest przekonywującym świadectwem spotkania z jednym z mongolskich władców, chociaż niekoniecznie $\mathrm{z}$ samym Kubilajem. W rodzinie toczyły sie spory o te złote tabliczki. Mogło tak stać się dlatego, że Marko Polo twierdził, iż był tam, gdzie go nie było. Być może jego ojciec i wuj mogli istotnie odbyć niebezpieczną podróż i powrócić $\mathrm{z}$ jedną lub więcej złotych płytek. a jedyna szansa sławy było dla Marko wykradzenie jednej z nich i przypisanie sobie, w czasie pobytu w niewoli, ich podróży". Wskazuje ona również, że testament Maffeo,

28. Ibn Battuta (1304-1368 lub 1369), urodzony w Tangerze w dzisiejszym Maroku. Rozpoczął swoje rozległe podróże w 1325 wyprawą do krajów arabskich, Persji, Azji Centralnej i Indii. Dotart do Chin w 1342 (drugim roku pawa przebywal do 1354. Książka powstala na bazie dykowanych przez niego relacji z tych podroży. Oryginał z języka arabskiego thumaczony był na języki europejskie. Istnieją również dwa przekłady chińskie. 
wuja Marko, sporządzony w 1310 r. sugeruje jakieś sztuczki z jedną ze złotych tabliczek mającej przypaść Marko (...) Wynika z tego, że skoro Marko Polo nie otrzymał żadnej złotej tabliczki, to nigdy nie dotarł do Chin; lub też innymi słowy, nie był on w Chinach i dlatego nie otrzymał złotej tabliczki (...).

Dr Wood traktuje tekst Opisania Świata jako dwie oddzielne całości: pierwsza podróż odbyta przez jego ojca i wuja opisana w Prologu (który uważa ona za wiarygodny), oraz drugą podróż, w której uczestniczył także sam Marko, $\mathrm{z}$ jakiej relację traktuje ona jako mieszankę legend i geograficznych oraz historycznych opisów. Według niej wiele źródeł książki Marko Polo pochodzi z zasobów i przekazów rodzinnych (...).

Chociaż dr Wood podjęła się trudu poszukania historycznych źródeł Opisania Świata, nie potrafiła jednak odpowiedzieć na pytanie, gdzie przez te wszystkie lata przebywał Marko Polo, ograniczając się jedynie do stwierdzenia „niestety, nic nie wskazuje na to, że był gdziekolwiek indziej". Był on w Chinach, lecz dr Wood uparcie odmawia uznania tego faktu. Stwierdza jedynie, że „Marko Polo nigdy nie zawędrował dalej jak do rodzinnych placówek handlowych nad Morzem Czarnym i w Konstantynopolu". [s. 150]

Argument odnoszący się do tych dwóch miejsc można nawet przyjąc (gdyż Marko Polo mógł rozpocząć podróż do Chin stamtąd), jednakże brak podstaw dla przypuszczeń o roli perskich przewodników czy Historii Świate Rashida al-Dina. Nigdy tego rodzaju przewodniki perskie nie zostały bowiem znalezione, i nawet jeśli jakiś zostanie odkryty, to będzie trzeba dokonać uważnych porównań, zanim będzie można wyciagnać jakiekolwiek wnioski. Co zaś tyczy źródeł do Historii Świata Rashida, ostateczne wnioski zostały wyciągnięte już dawno temu: została ona skompilowana przez Rashida alDina przy współudziale kanclerza Boluo, który był Mongołem, jak też dwóch chińskich uczonych, oraz osób z innych krajów, a ponadto na podstawie źródeł pisanych, w tym perskich i arabskich prac historycznych oraz Złotych prac w języku mongolskim. Marko Polo nie miał dostepu do takich materiałów, ani nie byłby w stanie ich przeczytać (...) Podobnie zwodniczym jest twierdzenie, że Opisanie Świata $i$ praca Ibn Batuty bazują na tych samych pisanych źródłach, tylko dlatego, że zawierają one opis wielkiego ptaka. Oba oni przebywali w Chinach i widzieli te same rzeczy, jest zatem naturalne, że mogli pozostawić podobny opis. Chcąc być konsekwentną powinna ona stwierdzić, że również Ibn Batuta nigdy nie był w Chinach.

Są oczywiście pomyłki, wyolbrzymienia i zmyślenia w książce Marko Polo, na przykład, zasługa zdobycia miasta Xiangyang, należącego do dynastii Południowej Song, przez Mongołów przypisana została głównie Polom, co nie odpowiada faktom. Opis tego wydarzenia różni się od opi- sów podawanych w źródłach chińskich i w Historii Świata Rashida al-Dina, i jest oczywistym przykładem samochwalstwa. Jednakże, relacje Marko Polo o najważniejszych wydarzeniach są w głównym zarysie poprawne, co potwierdza, że słyszał on o nich w Chinach. Z drugiej strony, różnice pomiędzy opisami Marko Polo, a tymi w Historii Świata pokazują, że dwa te dzieła opierały się na odmiennych źródłach. Brak jest również świadectw, że Marko Polo przez trzy lata sprawował funkcję urzędniczą w Yangzhou. Niektóre wersje mówią jedynie o jego ,pobycie" w Yangzhou. Istnieje wiele innych pomyłek wynikających z dawania przez Marko Polo wiary rozmaitym pogłoskom, czy z powodu złego poinformowania, usterek pamięci i jego lingwistycznej niekompetencji.

Jednak książka zawiera również wiele trafnych relacji, które stanowią cenne źródło odniesień, potwierdzających materiały chińskie. Na przykład, opis sytemu „prawa i sąów" w czasach dynastii Yuan: „Złodziej otrzymuje siedem, siedemnaście, dwadzieścia siedem, trzydzieści siedem ... albo sto siedem uderzeń kijem, w zależności od tego, co zabrał i od miary przestępstwa". Jest to wyjątkowy opis prawa karnego okresu Yuan i książka Marko Polo jest jedyną pracą z Zachodu, która go podaje. Innego przykładu dostarcza rozdział o Zhenjiang, w którym stwierdza się, że „w 1278 roku od urodzin Chrystusa nestoriański chrześcijanin imieniem Marsarchis zastal mianowany tam gubernatorem wielkiego Chana ... W okresie gdy mieszkal tam, przez trzy lata ... wybudował dwa chrześcijańskie ... kościoły". Marsarchis nie był ważną osobistością i nie ma jego oddzielnej biografii an nawet żadnej wzmianki o nim w Yuanshi. Jednakże w Zhishun Zhenjiang zhi (Encyklopedia Zhengjiangu powstała w 4 roku panowania cesarza Wenzonga $\mathrm{z}$ dynastii Yuan, to jest w 1333 r.) jego imię pojawia się $\mathrm{w}$ wielu miejscach: „Marsarchis był chrześcijaninem. W piętnastym roku panowania cesarza Zhiyuan został mianowany generałem Mingwei i zastępcą komendanta nadzoru rejonu drogowego Zhejiang. Mieszkał tam i wybudował siedem kościołów" ${ }^{\prime 30}$. Mamy zatem nazwisko osoby, czas, wyznanie religijne i wybudowanie kościołów, podane identycznie jak w przekazie Marko Polo (z wyjątkiem liczby kościołów). Być może Marko Polo widział tylko dwa, a resztę zbudowano dopiero później. Istnieje wiele innych podobnych przykładów. Jeśli Marko Polo nie byłby w Chinach i nie widział ani nie słyszał o tych zdarzeniach, jak mogłyby tak dobrze je przedstawić? Jeśli opisy te zaczerpnął z perskich przewodników, gdzie są owe tak dokładne przewodniki?

\footnotetext{
${ }^{30}$ Zhishun Zhenjiang zhi (Encyklopedia Zhengjiangu) powstała w okresie Zhishun [13301333], juan 18 .
} 
W ostatnim paragrafie dr Wood podsumowuje swe opinie na temat Opisania Świata i stwierdza: „Choć skłaniałam się do poglądu, że Marko Polo nigdy osobiście nie podróżował dalej niż do rodzinnych faktorii handlowych

nad Morzem Czarnym i Konstantynopola ... nie oznacza to, że Opisanie Świata przestaje być wartościowym źródłem informacji o Chinach ...Używane W połączeniu $\mathrm{z}$ arabskimi, perskimi i chińskimi tekstami, $\mathrm{z}$ których zapożyczył ducha, jeśli nie zawsze szczegóły, Opisanie Świata pozostaje bogatym źródłem". Jej ostatnie stwierdzenie jest niewątpliwie słuszne (...).

Przełozyt Janusz Kowalski 